\title{
Linguistic Refugees: to Migrate or to Translate Oneself? Female Migrant Writers' Experiences of Writing in Italian
}

\author{
Refugiadas linguísticas: migrar ou traduzir-se? A experiência de escritoras migrantes \\ na escrita em italiano
}

Anna Belozorovitch *

\begin{abstract}
This article explores the experiences of female migrant writers in Italy from East-Central Europe, regarding their literary production in a second language and building on interviews conducted by the author. The analysis takes into consideration the subjective necessity of expressing oneself in a second language to communicate contents that could not otherwise be expressed. The 'story' of how a new language was adopted by the writers reflects their expectations not only regarding their literary career but also of their life in a new country. The choice of using a foreign language within Italian publications is analysed regarding its communicative power, suggesting that both translating and avoiding translating participate in the literary work and its message. Finally, language is seen as experience and relationship; a place where it is possible to reveal a new (artistic) self. Although translation and selftranslation seem to be always implied in this context, the article suggests that translation is an inappropriate metaphor to describe writing in a second language.
\end{abstract}

\section{Keywords}

Migrant literature. Self-translation. Female writing. Second language.

\begin{abstract}
Resumo
Este artigo explora as experiências de escritoras migrantes na Itália originárias da Europa Centro-Oriental, em relação à sua produção literária em uma segunda língua e com base em entrevistas conduzidas pela autora. A análise leva em consideração a necessidade subjetiva de se expressar em uma segunda língua para comunicar conteúdos que de outra forma não poderiam ser expressos. A "história" de como uma nova linguagem foi adotada pelas escritoras reflete suas expectativas não apenas em relação à carreira literária, mas também à vida em um novo país. A opção pela língua estrangeira nas publicações italianas é analisada quanto ao seu poder comunicativo, sugerindo que tanto a tradução quanto a opção por não traduzir participam da obra literária e de sua mensagem. Por fim, a linguagem é vista como experiência e relacionamento; um lugar onde é possível revelar um novo eu (artístico). Embora tradução e autotradução pareçam estar sempre
\end{abstract}

\footnotetext{
* Sapienza Università di Roma.
} 
implícitas neste contexto, o artigo sugere que tradução é uma metáfora inadequada para descrever a escrita em um segundo idioma.

\section{Palavras-chave}

Literatura migrante. Autotradução. Escrita feminina. Segunda língua.

\section{'Accidental' language, 'natural' language}

The novel II paese dove non si muore mai by Ornela Vorpsi opens with a dedication "to the word humility, which is missing from the Albanian lexicon. Such a lack can give rise to very curious phenomena in the progress of a people" (VORPSI, 2005 , p. 3). Vorpsi's assumption recalls the idea that a language not only "thinks with us" and "for us", but "also makes think" the group of people who shares and uses it (ZAGREBELSKY, 2010, p. 4-6). The hypothesis that the lack of the term could correspond to the lack of the concept has long been a central discussion for linguistics and anthropology. Starting from the famous Sapir-Whorf hypothesis, the theory of linguistic relativity has generated numerous studies that have highlighted its complexity. In addition to Lakoff's thought, cited later in this article, we should remember the study by Gumperz and Levinson (1996), which offers a reinterpretation of the hypothesis in the light of more recent developments in fields of linguistics, cognitive sciences, and anthropology. In his essay "Through the Language Glass", for example, Deutscher shows how a language - although not directly involved - acts on perceptions of space and the sense of orientation (2011, p. 186-187). He also argues that certain fundamental aspects of thought depend much more on cultural conventions than we like to admit today. The mother tongue might be able to influence the way we remember, perceive and associate: mechanisms essential for our movement in the world (2011, p. 234-235). The possibility that experiences are conditioned by conceptual systems was also discussed by Lakoff, who, citing the work of the anthropologist Robert Levy and his famous study carried out in Tahiti, uses the concept of hypocognition: the lack of knowledge of a phenomenon, here an emotional one, due to a terminological void linked to its definition (LAKOFF, 1987, p. 310). Or again, analysing the terminology linked to the feeling of anger in the Anglo-American language, Lakoff explains that it is not a collection that has been accumulated by chance but rather structured parts of an elaborate cognitive model that remains implicit at the semantic level (1987, p. 408). Recognising, naming and defining certain 
phenomena, therefore, would seem to be passages in a circular movement of relationship between the mind and the world that passes through the language. As Chomsky states, there is no "furniture of the world" that is delivered to the door of every individual ready to be assembled: everything is human intervention, whether it is the most intuitive way of reading reality through common sense or this reading happens thanks to scientific instruments applied to physical or mental reality (1980, p. 218-219). Finally, with regard to the relationship between language and the existing world, we will recall Foucault when he suggests that "[the] great metaphor of the book that is opened, spelled, and read in order to know nature constitutes only the visible reverse side of a further, much deeper, translation, which forces language to reside on the side of the world, among plants, herbs, stones and animals" (1978, p. 49). The place of language would therefore be together with the objects it tries to name, a phenomenon which in turn becomes an object of knowledge (FOUCAULT, 1978, p. 51).

Taking a cue from the epigraph of Vorpsi's novel, I would like to reflect on some aspects of the choice or possibility of writing in a language other than one's mother tongue, bearing in mind the potential inherent in the use of a second language. Paradoxically, if the book had been written in Albanian, it would not have been possible to insert that dedication. Without risking unfounded claims, it is immediately possible to make a simple observation: that the new language makes it possible to write something that could not have been written in the original language. Taking a small step further, it is also possible to hypothesise that the text itself could not have originated elsewhere - that is, that the physical displacement of the author, from the point of view of the text, constitutes a sort of sine qua non. This possibility is more evident when considering texts written in Italian but regarding the country of origin: being directed to the Italian audience, they need to be explicit on phenomena that would not require explanation were the writer addressing his/her compatriots. Sometimes, that same distance that forces the writer to describe aspects of his/her country's life or history allows to elaborate complex personal or collective experiences, such as the life under a totalitarian regime (see BELOZOROVICH, 2019b). But these literary works can also regard the experience of migration, adaptation, the relationship with the new language and, while doing so, they participate in these processes, and vice-versa.

When Caruth analyses Freud's essay "Beyond the pleasure principle" (1920), she observes that the events that the father of psychoanalysis experienced during the 
period of work on the essay curiously traced the dynamics and phenomena he described. The relatively short text was composed in several countries, and terminating it elsewhere represented for Freud a new form of freedom, the freedom to "carry his voice to another place" (CARUTH, 1996, p. 23). Every story, suggests the scholar, both a personal one and the one that tells the History of a culture, is intimately linked to the notion of departure (1996, p. 23). Moving far away from the place of origin seems complementary and proportional to the process of speech formation. Moving away from one's home also offers a form of freedom, that of taking one's voice elsewhere. Freud himself writes about freedom, in commenting on that writing experience. Caruth notes, therefore, that the announcement of this freedom is possible in a new language, the language of the new place where the voice has been brought (1996, p. 23).

The relationship with the new language was one of the most important topics of discussion in a series of interviews I conducted in 2015 with ten authors from different countries of East-Central Europe, and that explored several subjects related to migrant writing. The research had a particular focus on violence and female migrant writing and converged into an extensive work that analised these subjects from different points of view (see BELOZOROVICH, 2019a). Part of the research consisted in discursive interviews which explored the beginning of writing, and of writing in Italian language, and the experience of being a migrant writer in Italy. In confirmation of what is hypothesised above, many of these authors immediately looked to Italian as a tool from which to start to locate their writing in a new space. An exception is given by the testimony of Barbara Serdakowski, whose somewhat conflicting relationship with the Italian language could be explained by the paradoxical situation of not having a sufficiently strong mother tongue to return to in case of danger: her writing language, before Italian, was French, in which the writer became less fluent after leaving Canada. In telling about the birth of the novel Katerina e la sua guerra (2009), she explains that the language in which the novel was written is to be considered "accidental":

I will never be able to have the bond I had with French, with a [different] language. Actually, I don't feel that I write in Italian. I feel that I am writing in the language [of the place] where I am living. [...] French was my own language. I could do like this [gestures as if manipulating an object in her hands], I did what I wanted. But I can't do that in Italian. (2015, p. 15-16, transcript, italics reflect vocal emphasis) ${ }^{1}$

\footnotetext{
${ }^{1}$ Here and in subsequent citations from interviews, translation is mine.
} 
The writing of Serdakowski's novel - focused on pain linked to the past, as the author explains when stating "I wanted to get closer to Poland" - started in conjunction with the feeling of mourning towards the mother tongue. And that feeling shines through her expressiveness as she talks about her writing experience. The abandonment of the mother tongue in her relationship with her own children had already set a similar precedent for her: "Changing language with a person", she explains, "changes a relationship" (2015, p. 17, transcript). This change would have resulted in a break in memory. According to Serdakowski, to use a language different from that heard by one's parents as a child means to interrupt that transmission of attitudes, forms of affection and subtly withheld teachings that pass from parents to children in moments of care and sharing. It must be said, although her work is not at the center of my analysis, that Barbara Serdakowski has written mainly poems, exploring a form of multilingual poetry (see Serdakowski, 2010) that combines verses in Spanish with verse in Polish, English, French and Italian: the languages of her life. This writing, possible only in the poetic field, she explains, constituted a necessity and at the same time a solution to her being in the midst of several linguistic worlds, devoid of stable references. In her prose and particularly in the case of Katerina e la sua guerra, the problematic knot is given not only by the reduced capacity of expression and by not feeling at ease in a language, but by another important deficiency: "what I hadn't expected", explains Serdakowski, was that "what I wrote was no longer available to my parents. To my family" (2015, p. 6, transcript).

A particularly important point here is the translation process linked to writing in a language other than the mother tongue, or in any case other than the previous writing language. I am referring not to the translation for another reader, but to the internal translation that takes place in order to produce the text. This phase seems to affect in different ways the interviewed authors, who witnessed differently their passage from one language to another. Anilda Ibrahimi, for example, starts writing prose for the first time in Italian, after writing poems as a girl in Albania. Her first novel, Rosso come una sposa (2008), was written directly in "a language that came naturally". The author says she never considered writing in Albanian and then self-translating: "I never doubted. I got up and wrote, without hesitation, without even asking myself 'in which language?"' (2015, p. 8, transcript). Anca Martinas, on the other hand, sees her writing in Italian as a space for growth. During the interview she is proud to note her growing mastery of Italian: 
I limited myself to expressing what I could express, but I refused to translate from Romanian into Italian. I wasn't looking for "Ah, how would this thing be better said" in Romanian and then translating it into Italian. No. I tried to express it in my own words, maybe in a poorer way, but directly in Italian, thinking in Italian. This was the challenge. [...] Not wanting to translate. (2015, p. 8, transcript, italics reflect vocal emphasis)

Irina Turcanu also describes her initial relationship with the Italian language as a challenge. She immigrated to Italy in late adolescence and had been passionate about writing while still living in Romania. She started writing in Italian for a very curious reason, namely the use of the internet. She says, in fact, that she joined online communities dedicated to writing where users, under a pseudonym, could share their texts. Since these websites were Italian, Turcanu began by translating her Romanian poems into Italian. She published under a pseudonym and did not disclose the fact that she was a foreigner. In learning Italian, she also sees a sort of duty towards the new country in which she lives, but she recognises in her first writing experiments a search for "consensus from the community"; the writing destined for the websites where she was registered, therefore, was produced with the specific intent of being recognised as valid by the other users, consequently legitimising the author's voice. With this strong stimulus behind her, she explains,

I did not even perceive the moment of the passage from one scripture, from one language, to another. It was almost ... natural, it came spontaneously. I was very anxious to learn Italian very well. [...] And therefore perhaps also for this reason I did not ask myself which language to choose. (2015, p. 12, transcript, italics reflect vocal emphasis)

\section{Between translation and 'elements of incomprehensibility'}

Turcanu publishes quite early, and her first novel, Alia, su un sentiero diverso (2008), contains numerous autobiographical elements. However, the problem of which language to choose doesn't seem to be solved at all: the text presents not only abundant references to Romania which, starting from the plot, informs the reader as much as possible about customs, traditions, even the most ancient history of the country, but also contains long passages in the Romanian language with translations by the author, as if to claim the uniqueness of each of the versions offered. During our interview, Turcanu speaks with some regret about that publishing experience, noting that perhaps she would not have done it if she could go back in time: she defines the book as a "Lonely Planet of the wonderful places in Romania" and excludes it from the 
category of fiction, because it is "fundamentally devoid of content, and instead full of references" (2015, p. 4-5, transcript). Such a personal text, says the author, can be considered a diary or a psychoanalysis exercise. In fact, she observes that the long passages in the Romanian language are symptomatic of the loneliness she was experiencing as a young immigrant, gripped by the anxiety ("crazy urgency", she stresses several times) to communicate the incommunicable (2015, p. 5, transcript).

It is worthwhile connecting Turcanu's self-critical observations to Caruth's analysis of Alain Resnais' film Hiroshima mon amour (1959) in reference to the presence of untranslated dialogue in Japanese. In fact, Caruth attributes an important communicative value to this "element of incomprehensibility" (1996, p. 44-46), since the very extraneousness and impenetrability of the discourse allows it to enter into a relationship with the recipient. The use of passages in a language other than Italian does not constitute a weakness of Turcanu: this expedient is used by several migrant authors of greater or lesser experience and varying frequency. It can be found, for example, in La lingua di Ana (2012) by Elvira Mujčić, which presents passages in Moldovan - mother tongue of the novel's protagonist. Caruth's reading can provide an illuminating starting point for interpreting similar choices: the speech in the other language, in fact, would open up the possibility of a story behind the foreign character. By making himself incommunicable, the Japanese man in Hiroshima mon amour shakes off the limited role of welcoming the French woman's narrative. The use of another language is also a representation of another past: a door (ajar) to a different story. The presence of the unreadable text is also a story of incommunicability. The "not wanting to translate" claimed by Martinas would thus constitute the other side of not being able to translate; yet, neither of them means not wanting or not being able to tell.

Translation offers us a metaphor for talking about the writing of migrant authors not only by thinking of a possible original language of the text, but also by considering the text as a path through which experience and memory come to the fore. The language of the texts, which in its peculiarities is different each time, in fact bears the mark of this translation, expressed in ways that do not always concern the use of other languages. From this point of view, Ornela Vorpsi's experience is unique: she began to write in Italian after moving to France, after only five years spent in Italy. But, she says, at a certain point she noticed that her Italian was deeply contaminated by French, no longer usable for writing and publishing. The way she describes her experience 
seems to attribute a weight of its own and a dynamic force to languages: "I told myself that I could no longer handle Italian". And she explains, "I could have held to Italian if it were my mother tongue", but weak as she was, she could not resist the "intrusion, the invasion of the French language" (2015, p. 5-6, transcript, italics mine).

Not only the end but also the beginning of writing in the Italian language constitutes a singular experience in Ornela Vorpsi's path. She writes her first short story in Italian, shortly after moving to France. She explains that it was something random, a form of compensation for the crisis she was experiencing as a painter, unable to find an environment where her style was recognised and her values shared. A French acquaintance, intrigued by her story, translated the text from the words of the author, who paraphrased it in French as she could. The story gave rise to the novel II paese dove non si muore mai (2005), which had the peculiar fate of being published first in France, in translation, and shortly after in Italy, in its original language. One aspect described by Vorpsi herself during the interview is quite significant: "the support [this translator] gave me was some kind of a land where I leaned and could write" (2015, p. 3, transcript).

The experience of translation, therefore, creates a space of possibility, an island between the unstable and fluid universes of non-mother tongues which Vorpsi manipulated. The image recalls that of "archipelagic thought" proposed by Glissant in relation to the translation process but also to the way of thinking about languages (1998, p. 36). Glissant, who defines translation as an art, observes that the translator finds himself faced with the need to invent a "necessary language between one language and another, just as the poet invents a language in his own language" (1998, p. 36). In fact, the scholar proposes to

\footnotetext{
think of the totality of languages in our imagination. The writer realises this totality through the practice of his language of expression and thus the translator makes it manifest, through the passage from one language to another, confronting himself with the uniqueness of each language. (1998, p. 36)
}

Already Sapir, in his essay Language: An Introduction to the Study of Speech, published in 1921, suggested that language itself was a collective art form and that literature constituted only an internal segment of it (2012, p. 69), helping to delineate the possibility of a space through which languages, texts and experiences can move. These reflections allow us to connect some of the different testimonies reported so far, 
also observing the shadow areas that can sometimes project themselves on the text. In the fascinating collection edited by De Courtivron (2003), bilingual authors of different origins share their perceptions of using languages, as well as their stories of relationship with them. According to Sylvia Molloy's experience, "[o]ne always writes from an absence, the choice of a language automatically signifying the postponement of another. [...] The absence of what is postponed continues to work, obscurely, on the chosen language" (2003, p. 73-74). Among the testimonies, the analogy between the change of language of expression and writing and the migratory event is very frequent. Anita Desai, for example, writes: "Having plunged off one coast, I had not really arrived on another. Instead, I found myself floundering midway", and again: "Once one has torn up one's roots, one becomes a piece of driftwood, after all, or flotsam. It is the tides and currents that become one's fluid, uncertain home" (2003, p. 14;17). Anton Shammas puts it even more explicitly: "If asked, I'd describe myself as a translator and linguistic refugee, a fugitive from three languages" (2003, p. 123, italics mine). Mujčić, too, during our interview, explains that her novel La lingua di Ana was born precisely from the need to narrate the encounter with the new language for an immigrant girl. She says that while many discourses are dedicated to the material difficulties related to migration, "the ferrying in the new language is never told" (2015, p. 7 , transcript). While the question has been widely witnessed by authors of migration (in addition to those already mentioned in this article, we must remember Eva Hoffman and her 1991 fundamental Lost in Translation), it is interesting to note the loneliness recounted by Mujčić, perhaps created by the feeling of uniqueness and incommunicability of the subjectively lived experience.

However, the dimension of flight that Shammas gives to this passage between languages deviates from the dynamics of any migration and is instead characteristic of the experience of a refugee. For Vorpsi, the drive to write, as we have said, was revealed at the moment in which painting, the artist's privileged expressive language, was going through a moment of crisis. Indeed, during the interview, in response to the question on how she started writing, Vorpsi begins by talking about her painting. The two arts, in fact, seem to constitute a single process which now finds one, now the other means of expression. So when the time came,

writing, let's say, took that place or filled this void, and gave me a justification ... to exist. Because in the end there is no need to justify one's life, one exists - full stop. But I, I needed to justify my existence to myself. (2015, p. 6, transcript) 
Before discovering writing, Vorpsi also dedicates herself to photography, which however does not give her the answers she seeks; she describes her condition before starting to write as a great "désarrol" (2015, p. 2, transcript), without finding the Italian word to indicate this feeling. Her arrival in writing is therefore a true story of escape in which different forms of artistic expression alternate in a way perfectly analogous to the alternation of the different languages available, in response to the same inner urgency. If, as Sapir hypothesised, literature is made up of two different arts, one linguistic and non-transferable, the other non-linguistic and capable of being translated without loss into a new language (2012, p. 68), then it is possible to think that this nonlinguistic component travels also through different forms of artistic expression. If the concept of self-translation, the subject of an increasing number of studies, may lead one to read into the prefix auto a suggestion of the autonomy and authority of the writer and of the one who translates (himself) (FERRARO, GRUTMAN, 2016, p. 10-11), the testimonies reported here highlight almost an authority suffered, a force that the language - one precise language - exerts on the writer, revealing to him or her a precise space in which it is possible to move.

It must be said that the authors interviewed and cited in this article debuted with novels strongly characterised by their female protagonists. Anlida Ibrahimi reached a certain celebrity with a family saga (2008) which starts in Albania and ends in Italy: at the end of the novel, the reader discovers that the narrating voice has always been the youngest woman of the family, who has migrated and is now transmitting in the written form the story of her family that had been transmitted orally before, from older to younger women. Ornela Vorpsi has been one of the most successful migrant writers in Italy, having debuted with a short novel (2005) whose protagonist, a young girl growing up under Albanian regime, moves to Italy at the end of the story. Young girls struggling between the past, in the country of origin, and the new life in Italy, are also main characters of the novels by the Romanian Irina Turcanu (2008) and the Serbian Elvira Mujčić (2007), who has also dedicated a book to the difficult relationship of a Moldavian girl with her new, Italian, language (2012). The first novels by the Romanian Anca Martinas and the Polish Barbara Serdakowski have adult, female protagonists who are fighting for their futures: In Serdakovski's novel (2009), though, the woman without a name will not be able to find peace. Escaped to Germany from war in Yugoslavia, she is restless, on the brink of madness: the only hope is for her daughter, Katerina, 
growing up in a European country and unconscious of her mother's past. Martinas' protagonist is also a tragic figure whose dream is to be free in Rome but whose destiny will be death (2009).

Although it is not the aim of this analysis, the gender component cannot be completely put aside when considering the literary work of female migrant writers. On the one hand, it is sometimes possible to observe recurring plots, and a tension between tradition and search for emancipation (see BELOZOROVICH, 2017); on the other, the same act of writing (and publishing) in a new language can be seen as a search for a "place in the world" (see MICELI, 2019), almost as an analogy of the Woolfian room of one's own. Therefore, the concepts of autonomy and authority previously mentioned acquire an even more profound meaning when considering these writers' relationship with a foreign language and the processes that lead them to adopt it as a language of literary expression.

\section{Languages of experience, experiences of language}

The authors were asked what their relationship was with their mother tongue and the possibility of writing in it. Vorpsi's response allows us to go back to the origin of her escape. When asked if she had considered going back to writing in Albanian, she replies no four times, and then: "I don't consider it", "Zero, I don't care at all, no interest", "I have no desire" (2015, p. 11, transcript). And further:

I need a language devoid of childhood. A language that does not bring childhood in it. With more distance [...] it is healthier for me, it is easier for me. [...] I need a language where childhood and family are completely removed and eliminated. (2015, p. 11, transcript)

If in the autobiographical novel II paese dove non si muore mai childhood is instead a very present dimension (the protagonists are often young girls described in their family context), Vorpsi explains: "I can write this childhood only because I subtract this [Albanian] language. [...] If not, I would choke on reliving. The foreign language is a perfect way to cool all this incandescent magma" (2015, p. 11, transcript). In fact, the author refers to a difficult experience that characterised her early years in Albania, and which has a central position in several of her works. The choice of one language simultaneously has the function of excluding another: it is the postponement of which Molloy writes, that continues to work in the dark, somewhere behind the text. 
Faced with an experience of suffering, on the other hand, the mother tongue seems to deprive itself of that familiar and welcoming dimension that should belong to it, accentuating the feeling of alienation and despair in those who want to externalise this experience (DAS, 2005, p. 221). Language, in fact, cannot be treated independently of its subject: the same language does not exist outside the word, as it is primarily a discourse (KRISTEVA, 1981, p. 325-326). Even before the language used is owned, before it is presumed to belong or not to belong to a place and to a people, there is the possibility of a deeper belonging to the one who uses it and makes it his own through the specific discourse. The language that the reader identifies as Italian inasmuch as he understands it (or not), is first of all, the language of the text in which Vorpsi - and other authors, each in a different way - infuses her own subjectivity.

The memory-bearing tale escapes the language it perceives as hostile or inadequate, yet it cannot refuse to be produced: memory needs the story to be able to assert itself (JEDLOWSKI, 2002, p. 60). This is because, explains Jedlowski, experience "cannot be reappropriated by the subject as a set of events endowed with a meaning: since the meaning can be constituted only in the language" (2002, p. 60). The narration does not simply use language, proposing a story: the language used reveals layers of information related to the belonging of the narrator. The act of narrating, Jedlowski again points out, translates the social being behind this narration into the very words that are used (2002, p. 59). Quoting Namer, the scholar reports how the current discourse on the traumatic experience of the past contains in itself "sedimentations of dialogues already carried out, of words and modes of the story that represent the survival of ties with the homeland and its languages" (2002, p. 60). It is interesting to consider this phenomenon in the light of the process of narration in a language that is not the one of origin, not the language in which the suffering was undergone and shared. It is possible to advance the hypothesis that the choice of another language has the ability to neutralise that layer of information otherwise impossible to manage and censor. The availability of this other language, then, allows the construction of memory - ultimately an individual one - with a higher degree of control over the material of which this memory is constituted, with direct repercussions for the identity of the writer.

Still referring to Vorpsi's writing experience, a final reflection on the use of a language (and in this case more than one) different from the mother tongue appears necessary. We often hear it said that migrant authors, thanks to their different origins 
and their experiences, make their contribution to the language itself, giving it that something extra that Italian authors are not able to express. Sometimes, the recognition of this contribution borders on a certain rhetoric which recalls feelings of exoticism, of indiscriminate but paternalistic benevolence towards the other. Migrant authors themselves often willingly appropriate this rhetoric when they are called upon to express an opinion on the issue at public events. When enhanced by prestigious publications, in fact, their different writing is presented as interesting precisely because of its non-total adherence to standard Italian. The recognition of this different quality also occurs on the part of publishers, and it is difficult to say whether (and when) it is objectively something precious to safeguard, rather than a small manufacturing defect which, through its suggestiveness, gives charm to the work. Regarding her passage from Italian to French and the difficulties that followed, Vorpsi says she perceives French as a "much more rigid" language, which "does not allow you to distort it as you want, the French will tell you: 'that's not French' [and] they don't joke. Instead with the Italians it was much more fun from this point of view" (2015, p. 6, transcript, italics mine). The personification that Vorpsi applies to languages suggests the presence of concrete individuals behind them. The distortion mentioned by the author is precisely the anomaly element caused by the foreign origin of the writer. Paraphrasing her words, in Italy this anomaly can be appreciated, in France it is considered an affront.

This generalisation must leave aside the broad debate around the question of how the anomaly of a foreign writer's language enriches a text, a debate that is unrelated to this analysis. What I want to underline, however, is that not all foreign languages are equally foreign, and this not because of the knowledge one possesses but because of the associations the languages create and the possibilities for selfconception that they offer to the individual. The image of the two languages that Vorpsi shared with me during the interview, realistic or not, do interfere with her personal experience. By changing the writing language, Vorpsi will accept the new rules whatever they are - and will be attributed, and perceived as having, a new identity as a writer.

Variation in how one uses language is common to every individual, foreign or not. Each person has different patterns of speech and the ability to use them according to the social context in which she finds herself (CHOMSKY, 1980, p. 216). The concrete differences between these models are not something that exists autonomously in nature but are the result of the action of individuals and groups that use their power to 
act directly on forms of language diffusion, such as literary production, imposing certain standards (KRISTEVA, 1981, p. 284). Chomsky argues that what we call knowledge of a language is primarily knowledge of grammar, while language is a result of the cognitive system interacting with that grammar (CHOMSKY, 1980, p. 90). Having grammatical competence means knowing a system of rules that refer to certain mental representations, while personal knowledge of the language - that is, knowing the conditions in which it is appropriate to use it and the purposes for which it can be successfully used - is intimately linked to systems of different knowledge (1980, p. 224-225).

Returning to the point from which we started, we can now see how learning a language and using it can also correspond to a more general knowledge of rules, which concerns the society that speaks that language. When Irina Turcanu explains that she felt compelled to become competent in Italian from the moment she was welcomed in Italy, she reveals a political dimension linked to linguistic choice, which can hardly be considered independent of the literary expression that passes through the language. The use of the latter also constitutes a request for acceptance and belonging, expressed through specific types of practices (ECKERT, MCCONNELL-GINET, 1995, p. 470). Turcanu speaks of the use of Italian in conjunction with her desire for approval by the community: the recognition of her Italian language - a second language incognito - corresponds to her entry into the new territory.

In the short journey undertaken in this essay, the starting position has been deliberately obscured, namely, whether, in mentioning migration literature, we want to talk about migrants who write or writers who migrate. Instead, we wanted to emphasise how the linguistic shift constitutes a more extensive shift of the self, and at the same time the construction of a new foreign self, where the relationship with languages far exceeds the instrumental dimension and becomes extremely personal and personified.

A final testimony worth citing in this regard is that of the Ukrainian poet Yurij Tarnavskij, immigrant to the United States and founder of a group of poets who spoke in Ukrainian: "I recall now that I used English in my diary quite soon after coming to the US. I wanted to be part of the world around me very badly", he writes (BARTOLINI 2012, p. 77). The use of another language even in such an intimate and personal space as one's own diary appears as a door stepping through which allows one to truly overcome national borders. 


\section{References}

BARTOLINI, Maria Grazia. “Nello stretto triangolo della notte...”. Jurij Tarnavs'kyj, il Gruppo di New York e la poesia della Diaspora ucraina degli USA. Rome: Lithos, 2012.

BELOZOROVICH, Anna. Dal ventesimo meridiano. Migrazione, violenza e scrittura femminile tra Est e Ovest europeo. Rome: Lithos, 2019a.

BELOZOROVICH, Anna. Messe alla prova: autrici migranti, trame ricorrenti. In M. S. SAPEGNO, M. S; PERROTTA, A.; DE BERNARDIS, I. (Eds.). Critica clandestina? Studi letterari femministi in Italia. Rome: Sapienza Università Editrice, 2017. p. 97106.

BELOZOROVICH, Anna. Writing from a Distance. The Past and the Present in Novels by Central and Eastern European Female Migrant Writers in Italy. Poznańskie Studia Slawistyczne, n. 17, p. 15-33, 2019b.

BUCHOLTZ, Mary \& HALL, Kira (Eds.). Gender Articulated: Language and the Socially Constructed Self. New York: Routledge, 1995.

CARUTH, Caty. Unclaimed Experience: Trauma, Narrative, and History. Baltimore: The Johns Hopkins University Press, 1996.

CHOMSKY, Noam. Rules and Representation. New York: Columbia University Press, 1980.

DAS, Venna. L'atto di testimoniare. In: DEI, F. (Ed.) Antropologia della violenza.

Rome: Meltemi, 2005. p. 215-246.

DE COURTIVRON, Isabelle (Ed.). Lives in Translation. New York: Palgrave Macmillan, 2003.

DESAI, Anita. Various lives. In: DE COURTIVRON, I. (Ed.). Lives in Translation. New York: Palgrave Macmillan, 2003. p. 11-17.

DEUTSCHER, Guy. Through the Language Glass: Why the World looks Different in Other Languages. London: Arrow Books, 2011.

ECKERT, Penelope, MCCONNELL-GINET, Sally. Constructing Meaning, Constructing Selves: Snapshots of Language, Gender, and Class from Belten High. In M. BUCHOLTZ, M.; HALL, K. (Eds.). Gender Articulated: Language and the Socially Constructed Self. New York: Routledge, 1995. p. 469-507.

FERRARO, Alessandra, GRUTMAN, Rainier. L'autotraduction littéraire: cadres contextuels et dynamiques textuelles. In A. FERRARO, R. GRUTMAN (Eds.).

L'Autotraducion littéraire. Perspectives théoriques. Paris: Classiques Garnier, 2016. p. 7-17.

FOUCAULT, Michel. Le parole e le cose. Archeologia delle scienze umane. Trad. E. 
Panaitescu. Milan: Rizzoli, 1978.

GLISSANT, Édouard. Poetica del diverso. Rome: Meltemi, 1998.

GUMPERZ, John J., LEVINSON, Stephen C. (Eds.). Rethinking Linguistic Relativity. Cambridge: Cambridge University Press, 1996.

HOFFMAN, Eva. Lost in Translation: A Life in a New Language. New York: Vintage, 1991.

IBRAHIMI, Anilda. Rosso come una sposa. Turin: Einaudi, 2008.

IBRAHIMI, Anilda. L'amore e gli stracci del tempo. Turin: Einaudi, 2009.

JEDLOWSKI, Paolo. Memoria, esperienza e modernità. Memorie e società nel XX secolo. Milan: Franco Angeli, 2002.

KRISTEVA, Julia. Le language, cet inconnu. Paris: Editions du Seuil, 1981.

LAKOFF, George. Women, Fire, and Dangerous Things: What Categories Reveal About the Mind. Chicago: University of Chicago Press, 1987.

MARTINAS, Anca. Dalla Romania senza amore. Rome: Robin, 2009.

MICELI, Simona. Un posto nel mondo: donne migranti e pratiche di scrittura. Cosenza: Luigi Pellegrini, 2019.

MOLLOY, Sylvia. Bilingualism, Writing, and the Feeling of Not Quite Being There. In: DE COURTIVRON, I. (Ed.). Lives in Translation. New York: Palgrave Macmillan, 2003. p. 69-77.

MUJČıĆ, Elvira. Al di là del caos. Cosa rimane dopo Srebrenica. Rome: Infinito, 2007.

MUJČıĆ, Elvira. E se Fuad avesse avuto la dinamite? Rome: Infinito, 2009.

MUJČIĆ, Elvira. La lingua di Ana: chi sei quando perdi radici e parole? Rome: Infinito, 2012.

SAPIR, Edward. Language: An Introduction to the Study of Speech. Memphis: General Books, 2012 [1921].

SERDAKOWSKI, Barbara. Katerina e la sua guerra. Rome: Robin, 2009.

SERDAKOWSKI, Barbara. La verticalità di esistere linearmente. Scandicci: L'Autore, 2010.

SHAMMAS, Anton. The Drowned Library (Reflections on Found, Lost and Translated Books and Languages). In: DE COURTIVRON, I. (Ed.). Lives in Translation. New York: Palgrave Macmillan, 2003. p. 111-128. 
TURCANU, Irina. Alia, su un sentiero diverso. Turin: Seneca Edizioni, 2008.

VORPSI, Ornela. Il paese dove non si muore mai. Turin: Einaudi, 2005.

ZAGREBELSKY, Gustavo. Sulla lingua del tempo presente. Turin: Einaudi, 2010.

Recebido em: 16/02/2021

Aprovado em: 25/03/2021 